\title{
KEY INHIBITING FACTORS OF INNOVATION ACTIVITY IN UKRAINE
}

\section{Nataliia Tymoshenko ${ }^{1}$}

DOI: https://doi.org/10.30525/978-9934-588-11-2_71

In modern economy the innovative component of development largely determines the structure of the national economy, the quality of created products and services, as well as the efficiency of functioning on the global markets, export opportunities and share in world's monetary income.

Despite some successes Ukraine is still in the transformation process that influence development of the innovation component. The research demonstrates the presence of a complex problems in this sphere. First of all there is a lack of a unified national innovation system in Ukraine.

State regulation of innovation activity and creation of a favorable innovation environment can act as a influential factor in the market transformation of the economic sphere of society. This requires the creation of an effective mechanism for reconciling the interests of all participants of the innovation process through carefully considered economic measures.

All inhibiting factors of development of innovations in Ukraine can be conditionally divided into two groups: problems of the state level and problems connected with innovative activity of the enterprises. Summarizing the available researches, we can distinguish the following factors of inhibiting innovation process at the enterprise level: lack of own funds; high costs of innovations; insufficient financial support from the state; high economic risk; long payback period for innovations; low solvent demand for new innovative products; lack of information on markets; lack of qualified staff; lack of funds from customers.

As can be seen most of the problems at the enterprise level are related to the financial and infrastructural components of innovation activity. Unfortunately, the enterprise itself is not able to overcome all these barriers to innovation activity, so this insist the urgency of introducing new mechanisms for the cooperation of government, science and business.

The key factors of inhibiting innovation process at the state level can be divided into: problems of legislative support (availability of number of uncoordinated programs, laws and regulations; problems with protection of intellectual property; harmonization of legislation in accordance with international requirements, etc.) and institutional problems related to development and functioning of the innovation activity infrastructure, which currently does not cover all the links of the innovation process and does not have a systematic approach to provide relevant services in the field of innovation activity for participants of the process.

In order to solve problems related to the financing of innovations at enterprise level it is important to introduce special programs and create innovative institutions within

\footnotetext{
${ }^{1}$ National Technical University of Ukraine «Igor Sikorsky Kyiv Polytechnic Institute», Ukraine 210
} 
the framework of innovation activity in order to find alternative sources of financing the innovation process, for example: special benefits for innovative enterprises; various forms of financial leasing; granting of state orders and control of the efficiency of the program-targeted forms for financing the priority directions of development. In our opinion, the development of innovative infrastructure and the establishment of its effective structure can give the necessary impetus to the rapid innovative growth of Ukraine.

Given the scarcity of investment and financial resources, it is advisable to focus on innovative development of specific territories of high technologies and productive areas. However it should be remembered that effective innovation process is possible only if there is a mutually beneficial partnership between government, science and business. Separately, neither the state nor business is able to move the economy to an innovative path.

\section{References:}

1. Heyets, V. M. (ed.) (2015). Innovatsiina Ukraina - 2020: Natsionalna dopovid [Innovative Ukraine 2020: National Report]. Kyiv : NAS of Ukraine. (in Ukrainian)

2. Madzhara, O. V. (2011). Sotsialno-ekonomichni faktory halmuvannia innovatsiinykh protsesiv na pidpryiemstvi [Socio-economic factors of inheritance of innovation processes at enterprise]. Naukovyj visnyk Uzhghorodskoho universytetu, Seriia Ekonomika, 33(4), 94-97. (in Ukrainian) 